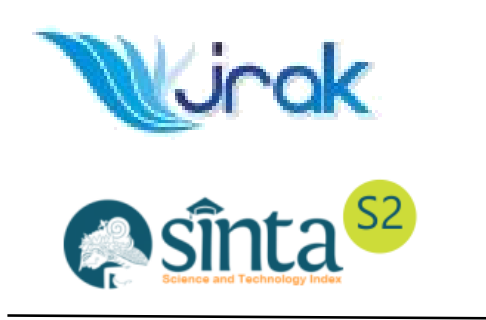

Website:

ejournal.umm.ac.id/index.php/jrak

Afiliation:

${ }^{1}$ Universitas Kristen Satya Wacana, Salatiga, Central Java, Indonesia

*Correspondence:

232016147@student.uksw.edu

DOI: $\underline{10.22219 / j r a k . v 10 i 1.11430}$

Citation:

Artati, A.K., \& Noviyanti. (2020).

Fraud Risk Assessment:

Experimental Study On The

Alternative Fraud Model

And Auditor Risk Preferences.

Jurnal Reviu Akuntansi dan Keuangan, 10(1), 21-37.

Article Process

Submitted:

March 2, 2020

Reviewed:

April 1, 2020

Revised:

April 3, 202

Accepted:

April 5, 2020

Published:

April 13, 2020

Office:

Department of Accounting

University of

Muhammadiyah Malang

GKB 2 Floor 3.

Jalan Raya Tlogomas 246,

Malang, East Java,

Indonesia

P-ISSN: 2615-2223

E-ISSN: 2088-0685
Article Type: Research Paper

\section{Fraud Risk Assessment: Experimental Study On The Alternative Fraud Model And Auditor Risk Preferences}

\author{
Arintyas Kristi Artati ${ }^{1 *}$ and Suzy Noviyanti ${ }^{1}$
}

\section{ABSTRACT}

Fraud risk assessment is an important part of the audit process and one of the toughest challenges faced by auditors. In considering fraud risk assessment, fraud models and risk preferences can influence auditor's decisions. This study uses a $2 \times 2$ between-subject experimental design with a total of 110 auditors of public accountant firms in Central Java as participants and produces 60 data ready for processing. Participants were formed into 4 groups with different treatments which the treatments consist of Diamond Fraud model with high and low risk preferences and Pentagon Fraud model with high and low risk preferences. The results show that the use of Pentagon Fraud model will result a more conservative fraud risk assessment. When auditors dare to take high risk action, the resulting fraud risk assessment will be low. In addition, the fraud model and risk preference variables show a significant influence on the performing of fraud risk assessment. There is an interaction between fraud models and auditors' risk preferences in the performance of fraud risk assessment.

KEYWORDS: Fraud Model; Fraud Risk Assessment; Risk Preference. 


\section{INTRODUCTION}

Fraud in financial statements still has been the focus of auditors and it is difficult to detect fraud (Bakhteev, 2015). Fraud in financial statements occurs when the management deliberately misleads users of financial statements by manipulating financial statements. Chief Executive Officers (CEOs) of large audit firms recognize the importance of fraud detection by auditor and there are criticisms from business circles concerning the value of audits that lack focus on fraud detection. Stakeholders rely heavily on auditors as the "watch dogs" to help them managing fraud risks and protecting public investments (Boyle, Dezoort, \& Hermanson, 2015). The Asia Pacific region has suffered most from the impact of fraud with $80 \%$ of misuses of assets, $51 \%$ of corruptions, and $13 \%$ of frauds on financial statements (ACFE, 2018).

The type of fraud in Indonesia with the greatest impact of losses according to the survey of Association of Certified Fraud Examiners (ACFE) is corruption (ACFE, 2016b). Fraud in the form of corruption can also occur in large companies, such as in the case of fraud of PT Garuda Indonesia's financial statements which the public accountants were negligent in conducting their audit at PT Garuda Indonesia (CNN, 2018). To eradicate fraud cases, public accountants (AP) are needed to audit, evaluate and provide opinions regarding a fraud occurring in a company. When conducting an audit, a public accountant must comply with applicable Audit Standards (SA) because it greatly influences the assessment about public accountants. Kasner Sirumapea, Tanubrata, Sutanto, Fahmi, Bambang, and their associates from the public accountant firm had committed a number of omissions in assessing accounting activities, recognition of receivables and other incomes. They recognized the receivables though their nominal values have not been received by the company. The case indicates that fraud in financial statements can be detrimental to many parties.

Data presentation which is not in accordance with the actual conditions in the financial statements can cause the shown information is irrelevant to be used as material for decision making. A financial statement that has been manipulated will result a great loss for investors and they will not get capital return for their investments (Eulerich, Georgi, \& Schmidt, 2019). Auditors' negligence has prompted the American Institute Certified Public Accountant (AICPA) to publish a standard for auditing. The Statement of Auditing Standards No.99 (SAS No.99) was issued to increase the effectiveness of auditors in detecting frauds by assessing various risk factors in industrial frauds. The theory underlying a factor of fraud risk is the Fraud Triangle. This theory was coined by Cressey (1953) that illustrates various fraud risk factors. There are three general conditions that cause fraud in financial statements, namely, pressure, opportunity, and rationalization (Abayomi, Sorunke, 2016).

Literatures that describe frauds in accounting dominated by the concept of the Fraud Triangle as a theoretical framework for understanding the causes of fraud and evaluating the factor of fraud risk that have impacts on financial reporting (Vousinas, 2019). Fraud Triangle is a concept that explains that the occurrence of fraud depends on the pressure to commit fraud, the opportunity to commit fraud, and the capacity to rationalize errors (Bakhteev, 2015). Although Auditors in detecting fraud can use the fraud triangle model, in reality, frauds still frequently occur in various companies. Auditors are often questioned for their ability to detect fraud. Hammersley (2011), highlighted the ongoing concerns about an auditor's ability to identify relevant fraud risk based on the fraud triangle theory. Many

JRAK 10.1 
academics consider that there are fraud-related research models that have more detail concepts than the concepts in the fraud triangle model (Sonu, Ahn, \& Choi, 2017).

Simon, Smith, \& Zimbelman (2018), stated that Wolf \& Hermanson in 2004 had introduced the Diamond Fraud model to develop the Fraud Triangle. The component of capacity was incorporated into concepts that serve to encourage the capacity of individuals to act on opportunities to commit fraud. The dimension of capacity includes elements such as expertise which is needed to exploit opportunities of fraud, the capacity to force others to commit or hide fraud, and the capacity to lie effectively. Currently, the Diamond Fraud model has been developed into the Pentagon Fraud model by adding the factor of arrogance. The Pentagon Fraud theory found by Crowe explains about the elements of fraud namely, pressure, opportunity, rationalization, capability or competence, and arrogance (Crowe, 2011). These five elements show the existence of financial and nonfinancial factors used as indications of the causes of fraud on a company's financial statements.

Abayomi, \& Sorunke (2016); Anisykurlillah (2016); Utami, Noviyanti, Wijono, \& Mohamed (2019), have provided empirical findings with the same variable which show that all factors in the Diamond Theory have an influence on the intention to commit fraud. Rengganis, Sari, Budiasih, Wirajaya, \& Suprasto (2019), described that the diamond theory in reporting of financial statements which pressure has a positive impact on fraud on financial statement, opportunity has a negative impact on fraud of financial statement, and rationality and capacity do not have an effect on fraud of financial statements. However, Septriani \& Handayani, (2018) have different research results which someone's arrogance for having good position can make him confident that internal control will not be applied to him. There are several studies which show that arrogance can be a motive for someone to commit fraud, such a research conducted by Devi, Wahyuni, \& Sulindawati (2017), and researches conducted by Apriliana \& Agustina, (2017); Bawakes, Simanjuntak, \& Daat (2018), and Vousinas (2019) which state that a factor of arrogance has an influence on fraud of financial statement.

Fraud risk can be reflected in the habits and traits of the leaders, managers and employees who justify the misappropriation of financial statements and misuse of assets. Cohen (2011), stated that the intention to commit a fraud is based on the theory of planned behavior which individuals' personalities becomes a factor of intention to commit a fraud. Each person has his/her own personality in dealing with a risk. The research results about Diamond Fraud model and Pentagon Fraud model show that an error in specifying a risk might affect auditor's preferences concerning the factor of fraud risk and fraud risk assessment.

Detection of fraud that is conducted by an auditor in the general audit process faces several problems. The fraud model is one of factors to determine the fraud risk assessment. There has been a development in fraud models which auditors can use different fraud models in considering fraud risk assessment. The development of fraud models certainly affects the auditor's judgment when he determines the fraud risk assessment. Risk preference is also a factor when an auditor wants to determine the fraud risk assessment. Fraud risk assessment is an important part of the audit process and one of the toughest challenges faced by auditors. Fraud risk assessment that can be done through various frameworks can make audit activities more effective.

Recently, fraud models have been well developed in detail to reveal the triggering factors of fraud. This study will compare the Diamond Model and Pentagon Model related to risk 
preferences to determine the fraud risk assessment. Thus, questions can be drawn: Are auditors who use the Pentagon Model more conservative than auditors who use the Diamond Model? Are auditors who have low risk preferences more conservative than auditors who have high risk preferences? Do auditors who have high risk preferences in using of Pentagon Model tend to produce more conservative fraud risk assessment?

The aim of this study is to examine the causality of fraud models with fraud risk assessment and examine the effect of auditor risk preferences on fraud risk assessment. This study also examines the interaction of fraud models with risk preferences in performing fraud risk assessment. Theoretically, this study contributes the literatures of fraud risk assessment by investigating fraud models. Practically, this study provides input for the professional association of public accountants and public accounting firms to improve the ability of auditors in performing of fraud risk assessments through various appropriate trainings.

Actions of fraud have grown rapidly over the past few years and also there is a growing trend for big organizations to hire professionals such as forensic accountants to reduce the pressure and potential for financial fraud. The task of a forensic accountant is to collect systematic financial data, analyze and interpret complex financial problems and respond to complaints arising from criminal and civil problems as well as questions arising from investigations (Simon et al., 2018). ACFE (2018), defines occupational fraud as the process of using someone's works or responsibilities to satisfy his personal interests to enrich himself through deliberate abuse of power. The abuses of power that are done by perpetrators of fraud include deliberate mismanagement and misrepresentation of organizational resources (Abdullahi \& Mansor, 2015). There are various categories of financial crime such as fraud and breach of trust done by employees.

Fraud in general is an act to take benefit from making the wrong presentation (Annisya, Lindrianasari, \& Asmaranti, 2016). In fact, fraud in financial statements is done deliberately by giving a false information in the financial statements. Cressey stated that there are three conditions that are always present in the event of fraudulent financial statements i.e. pressure, opportunity, and rationalization (Cressesy, 1953). The perceived pressure refers to factors that lead to unethical behavior. Every perpetrator of fraud faces a pressure to engage in unethical behavior. This pressure can be in the form of financial pressure or nonfinancial pressure (Sadikin \& Adisasmito, 2016).

The second important element of fraud is the perceived opportunity. Opportunity is created through ineffective controls or governance systems that support a person to commit organizational fraud. In the field of accounting, this is referred to as a weakness of internal control. The concept of perceived opportunity shows that people will take advantage of the circumstances available to them (Abdullahi \& Mansor, 2015). The third element of fraud is rationalization. Rationalization is an attitude that allows individuals to commit fraud or to rationalize fraud (Free, 2015)

Figure 1.

Fraud

Triangle

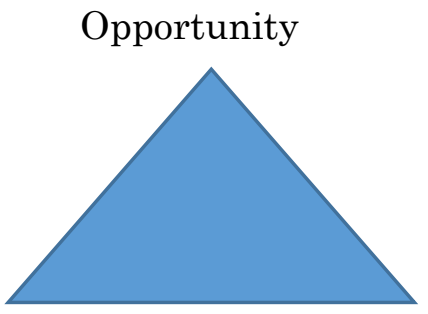

Rasionalisation

Motivation

JRAK

10.1 


\section{Diamond Fraud}

Preassure

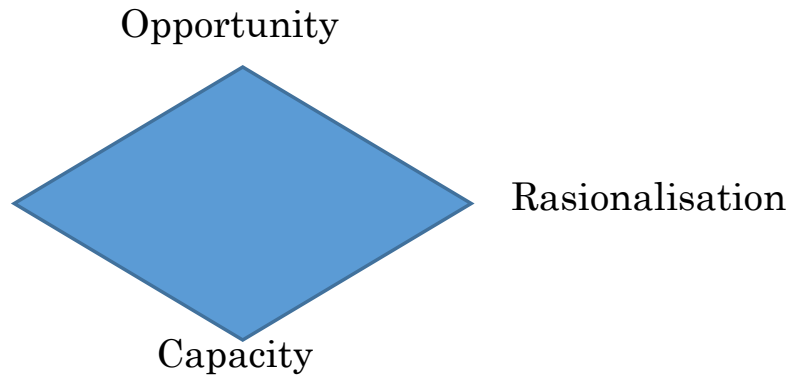

Figure 2.

Diamond

Fraud

Fraud Diamond is the new view about a phenomenon of fraud proposed by Wolfe \& Hermanson in 2004 (Vousinas, 2019).Wolfe and Hermanson argue that fraud will not occur without the right people with the right abilities. There are 6 elements owned by fraud perpetrators, namely, position/function, intelligence, level of self-confidence/ego, coercive ability, effective lying and immunity to stress (Nugraheni \& Triatmoko, 2016).

Wolfe and Hermanson argued that although perceived pressure or incentive might coincide with opportunity and rationalization for fraud, it is impossible for a fraud to occur unless the fourth element is present i.e. capacity. Potential perpetrator must have skills and abilities to actually commit a fraud (Ruankaew, 2016). Simon et al., (2018), stated that the capability component is included in the framework that serves to include the capacity of an individual to act on opportunities to commit fraud. This capability dimension includes elements such as the expertise needed to exploit opportunities for fraud, the capability to force others to commit or hide fraud, and the ability to lie effectively (Artani \& Wetra, 2017).

Over time, Fraud Diamond has been developed into Pentagon Fraud by adding a variable of arrogance as a motive for someone to commit fraud. The Pentagon Fraud framework was developed by Crowe Howarth. Bawakes et al., (2018), stated that a high level of arrogance can lead to fraud. A fraud that is based on Pentagon Fraud framework consists of five factors that can cause fraud, namely, pressure, opportunity, rationalization, capability, and arrogance. Arrogance is a behavior of superiority and greed from committing of a crime by not applying a company's policy and procedure (Akbar, 2017).

The arrogance owned by a person has can prompt him to consider that any internal controls will not be applied to him because of his status and position, so there is no guilty feeling when he commits a fraud. Arrogance is one's pride and desire to be praised, respected by others because of one's improving performance (Vivianita \& Indudewi, 2018). Septriani \& Handayani (2018), stated the feeling of arrogance owned by someone with his high position that he has can make him confident that internal control cannot be applied to him. Because arrogance can be a motive for someone to commit fraud, arrogance can be a factor that influences the fraud in financial statements (Vousinas, 2019).

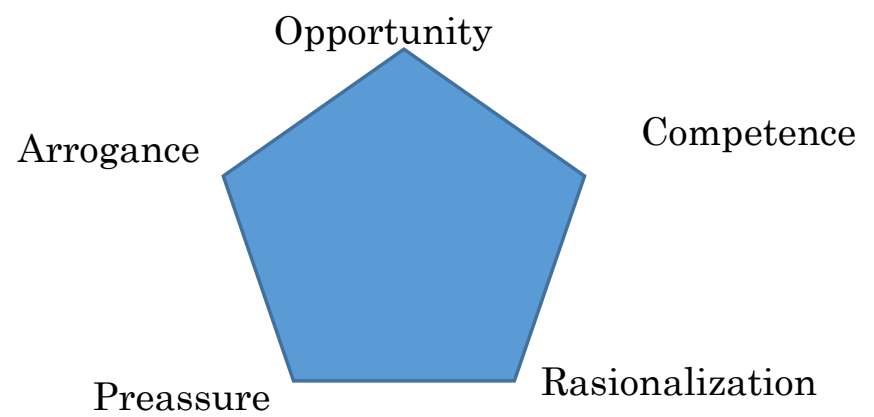

Figure 4.

Pentagon Fraud 


\section{Risk Preferences}

An auditor in providing his fraud risk assessment has a potential to be influenced by internal factors within him. One of internal factors that can affect auditors is bias that can cause a halo effect. A halo effect is defined as a tendency of evaluating of a subject influenced by generalization from one aspect of assessment that affects the whole aspect of the assessment (Utami, Kusuma, Gudono, \& Supriyadi, 2014). Auditors tend to categorize the influencing things when they make decisions. One of the individual factors that influence decision making is risk preference (Niemi, Knechel, Ojala, \& Collis, 2018). In capital market, risk preference consists of conservative and non-conservative risk preference. Conservative investors tend to be more cautious or suspicious in making their decisions while non-conservative investors tend to be aggressive in making their decisions that only rely on their habits.

Risk preferences can be interpreted as a tendency to behave to get rewards that can cause losses such as criminal acts that can damage one's mental and physical (Steinberg, 2013). Risk preference is one's condition when he placing himself in danger situation that can lead to the loss of valuable things (Hoffmann, 2019). Risk preference is one's attitude towards a risk and risk preference is used to determine the characteristic of someone in his/her making decision (Wen, He, \& Chen, 2014). Risk preference tend to focus on a behavior that involves higher variation, regardless whether it is beneficial or detrimental (Sonu et al., 2017). Individuals when they face a risk, they will have three tendencies, namely, avoiding the risk, being neutral about the risk and facing the risk. In an auditor's assignment, he must implement the general standards which state that an auditor must be skeptical. An auditor's skepticism plays an important role when he wants to consider risk in financial misstatements (Trompeter, Carpenter, Desai, Jones, \& Riley, 2013).

Fraud risk assessment is a process of proactively identifying and dealing with an organization's vulnerability to internal and external frauds (ACFE, 2016b). Hammersley (2011), highlighted the role of auditors when conducting fraud risk assessment in the audit process and highlighted the effect of auditor risk assessment on the level of testing. Specifically, Boyle et al., (2015), developed a planning task model in relation to a fraud made by an auditor that begins with auditor's characteristics (i.e. motivation, experience, knowledge, ability) and the characteristics of fraud risk factors (general and specific) that influence the results of auditor's fraud hypotheses, fraud risk assessment, and the program audit. The focus in this study is that the study discusses variations in the assistance of fraud risk practices (based on an alternative fraud framework) that influences auditor's fraud risk assessment (Utami \& Nahartyo, 2013). Specifically, this study uses various characteristics of auditor (such as level of experience and skepticism) to consider the extent to which fraud models influence an auditor's consideration of fraud risk factors.

This study discusses fraud models used by auditors in carrying out risk preferences (Eulerich, Georgi, \& Schmidt, 2019). Simon et al., (2018), stated that fraud models have benefits in conducting fraud risk assessment. Meanwhile, Hammersley (2011), stated that fraud models can show various signs of fraud threat. There, the auditor will consider maybe through brainstorming strategies - specific deception methods as well as concealment and transfer techniques. The auditors use this information to formally develop an independent risk assessment of fraud and to determine the appropriate fraud detection effort based on the level of risk to be detected (i.e. the risk that the auditor does not detect a material error due to fraud) (Trompeter et al., 2013). The model suggests that fraud detection procedures should be designed in the audit program for the triangle of fraud as

JRAK 10.1 
well as for the elements of fraud (i.e., the act itself, the concealment of fraud or the conversion of fraudulent gains) (Payne \& Ramsay, 2005) .

An individual's feeling about his high position and high ability above other individuals shows his high degree of arrogance that in turn will influence his intention to commit a fraud (Vousinas, 2019). An individual who has a tendency to face risk will use all necessary means to realize his desire. Boyle et al., (2015), argued that the use of Pentagon Fraud model will result a more comprehensive evaluation of fraud than the use of Diamond Fraud model. Based on the results of previous studies, the first hypothesis can be formulated as follows:

$\boldsymbol{H}_{1}$ : An auditor who uses Pentagon Frand model will tend to implement a more conservative fraud risk
assessment than an auditor who uses Diamond Fraud model

Risk preference tend to focus on behaviors that involve higher variation, regardless whether they are beneficial or detrimental (Rigoli, Preller, \& Dolan, 2018). All Individuals when they face risk, they will show three tendencies, namely, avoiding risk, being neutral about risk and facing risk. Pressure, opportunity, and rationalization are elements of fraud risk that are often studied with a large number of literatures discussing about the relationship between triangular elements of fraud and fraudulent financial reporting (Ruankaew, 2016). This study also connects auditors with risk assessment fraud (Johnson \& Silverman, 2010). Hammersley (2011), considered that auditors' assessment models in fraud-related tasks show that concerns about unethical leadership can affect the auditors' mental representation and the results of fraud hypotheses to anticipate fraud risk assessment.

Risk preference tends to focus on behaviors involving higher variance in audits, regardless whether they are beneficial or detrimental (Cotter \& Hanly, 2010). Auditors with high risk preferences have a high level of confidence and they are bolder in taking high risks. When auditors dare to take high risks, the resulting fraud risk assessment tends to low.

Based on the opinions of experts and the aforementioned arguments, the second hypothesis can be formulated as follows:

$\boldsymbol{H}_{2}$ : An auditor who has a low risk preference tends to be conservative compared to an auditor who bas a bigh risk preference

The auditors may also consider specific schemes for fraud and concealment. The auditor then develops a fraud risk assessment and determines the fraud detection procedures based on the level of risk to be detected (i.e. the risk that the auditor does not detect a material error due to fraud) (Trompeter et al., 2013). Fraud risk assessment is a process of proactively identifying and dealing with an organization's vulnerability towards internal and external frauds (ACFE, 2016a). Auditors need a fraud model in conducting their fraud risk assessments. An individual who has a tendency to face risk will use all necessary means to realize his desire. Boyle et al., (2015), argued that the use of Pentagon Fraud model will result a more comprehensive evaluation of fraud than the use of Triangle Fraud and Diamond Fraud models

Chen, Shapeero, \& Kong (2016), concludes that risk aversion is one of the psychological factors influencing decision-making that greatly impact investment performance and earnings management. However, most of the existing literature has adopted indirect approaches to investigate the relationship between risk preference and CEO's financial statement fraud, such as exploring the negative impact of risk preference on managerial business decisions, which consider that negative economic results ultimately lead to 
management accounting fraud (Hoffmann, 2019). Risk preference also affects an auditor's decision making. An auditor with a high risk preference tends to have courage in taking high risks. An auditor who has a high risk preference will tend to be conservative in conducting his fraud risk assessment. Fraud model and risk preference can help auditors in making a more accurate fraud risk assessment.

Based on the above discussion, the third hypotheses can be formulated as follows:

$\boldsymbol{H}_{3:}$ An auditor with a high risk preference will tend to produce a more conservative frand risk assessment using Pentagon Fraud model

\section{METHOD}

This study was conducted using a factorial design of experimental laboratory. The advantage of experimental design is its ability to prove stronger of a causal relationship (Boyle et al., 2015). The used factorial design was between $2 \times 2$ subjects design. The first independent variable to be tested was the fraud model consisting Diamond Fraud and Pentagon Fraud models. The second independent variable to be tested was risk preference consisting high and low risk preferences. The dependent variable to be tested was fraud risk assessment.

The subjects of this study were auditors of public accounting firms who attended an audit seminar in Semarang on 23 and 24 September 2019. The method in collecting data was done randomly. The distribution of the experimental modules was carried out randomly in order to ensure that each group consists of heterogeneous subjects. In responding of modules, subjects were only influenced by the manipulation provided and not influenced by their demographic characteristics. Table 1 shows the matrix of research experiments that is divided into 4 groups.

The experiment was started by distributing modules to the subjects (auditors) of the study randomly. Subjects filled out their respective identities in the modules consisting of tenure; gender; number of audit training that they attend in 1 year; position the public accounting firm; latest education and age as their demographic characteristics. Next, the subjects read the public accounting firm profile and their roles in the trial as an auditor that has a task to make an assessment of fraud risk factor of financial statement. Next, after they provided profile information, subjects were asked to rate on a scale from 0-100 on each fraud hint. After a subject assessed the fraud instruction, they had to answer three questions to ensure that they understand about their roles and duties. After a subject answered at least two of the three questions correctly, the subject would be considered as having a good understanding about their roles and tasks in the experiment.

Next, subjects received manipulation of risk preferences (high or low). Subjects who chose high risk preference are described as very confident, selfish, have focus on profit and the client's trust in the public accounting firm. Conversely, subjects who chose low risk preference are described as lacking confidence, persuasive, not focused on the profit and client's trust in the firm. Next, subjects received fraud models showing the manipulation of Diamond Fraud and Pentagon Fraud with two versions of scenario, namely, high and low.

Table 1. Experimental Matrix

\begin{tabular}{llll}
\hline \multirow{2}{*}{ Fraud Model } & & \multicolumn{2}{l}{ Auditor's Risk Preference } \\
\cline { 3 - 4 } & & High & Low \\
\hline Fraud Diamond & High & Group 1 & Group 2 \\
Fraud Pentagon & Low & Group 3 & Group 4 \\
\hline
\end{tabular}


Indicators for Diamond Fraud consist of pressure, opportunity, rationalization and capability. Indicators for Pentagon Fraud consist of pressure, opportunity, rationalization, capability and arrogance.

Manipulation ended with a manipulation check by asking five questions about the manipulation given. Subjects who answered at least three questions correctly passed the manipulation check. The experiment ended with interviews showing the appreciation for the seriousness of subjects in completing the simulation as shown in the debriefing session.

\section{Techniques of Analysis}

This study uses the testing stage of manipulation checking with an aim to determine whether a subject passes or does not pass the manipulation checking. The next stage is descriptive testing of subjects and effectiveness testing of randomization using One Way Analysis of Variance (ANOVA). Randomization testing aims to determine whether the characteristics of a subject affect his decision making on fraud risk assessment. Randomization is considered as successful if a subject's characteristics influence the subject when he fills out modules. The first and second hypotheses testing were processed using mean difference test (independent t-test). The third hypothesis was tested using Two-Way Anova to find out whether there is an interaction between two independent variables. A hypothesis is accepted if the Sig value is smaller than alpha (0.05).

\section{RESULTS AND DISCUSSION}

\section{Overview of the Study}

The series of experiments were held on September 23 and 24, 2019 at the Audit Training Seminar in Semarang, Central Java. Participants in this study consist of 100 auditors from a private public accounting firm which the participants were divided into 4 groups. 60 auditors as participants were manipulated and passed 5 manipulation questions related to roles, tasks and manipulation statements related to fraud risk assessment. Demographic characteristics of the subjects in this study are gender, tenure, position in the public accounting firm, number of last year's audit training, latest education, and age as shown in Table 2.

The table shows that the participants' demographic characteristics are varied considerably. Participants in this study are dominated by male auditors (53.3\% participants). The majority of participants had tenures of 3 to 5 years in public accounting firms (36.7\% participants). Participants who attended 3 up to 5 times of last year's audit trainings are $46.7 \%$ participants. The position of senior auditor dominates the number of participants in this study (36.7\% participants). Most participants had undergraduate degree $(48.3 \%$ participants). The age range of participants was 20 to 40 years old and most participants were 30 years to 40 years old (53.3\% participants).

\section{Manipulation Checking}

Manipulation checking of the fraud models and risk preferences for auditor's fraud risk assessment was done through comprehension test of roles and conditions faced by subjects

JRAK of this study. The subjects of the study were given several questions related to research information on each manipulation. 60 subjects passed the checking of manipulation.

10.1

Based on the results of manipulation checking, all subjects had received manipulations in accordance with the fraud models and risk preferences for fraud risk assessment. These results can be used for further testing. 


\begin{tabular}{|c|c|c|c|}
\hline \multicolumn{2}{|c|}{ Demographical Characteristics } & \multirow{2}{*}{$\begin{array}{l}\begin{array}{l}\text { Number } \\
\text { Participant }\end{array} \\
32\end{array}$} & \multirow{2}{*}{$\begin{array}{l}\text { Percentage (\%) } \\
53.3\end{array}$} \\
\hline & Male & & \\
\hline Gender & Female & 28 & 46.7 \\
\hline \multirow{4}{*}{ Tenure } & $<3$ years & 11 & 18.3 \\
\hline & $>3$ to 5 years & 22 & 36.7 \\
\hline & $>5$ to 8 years & 21 & 35.0 \\
\hline & $>8$ years & 6 & 10.0 \\
\hline \multirow{3}{*}{$\begin{array}{l}\text { Last Year's Number } \\
\text { of Audit Training }\end{array}$} & $<3$ times & 10 & 16.7 \\
\hline & $>3$ to 5 times & 28 & 46.7 \\
\hline & $>5$ times & 22 & 36.7 \\
\hline \multirow{4}{*}{$\begin{array}{l}\text { Position in the public } \\
\text { accounting firm }\end{array}$} & Staff & 15 & 25.0 \\
\hline & Junior Auditor & 21 & 35.0 \\
\hline & Senior Auditor & 22 & 36.7 \\
\hline & Audit Manager & 2 & 3.3 \\
\hline \multirow{3}{*}{ Recent Education } & Underoraduate & 29 & 48.3 \\
\hline & Graduate & 25 & 41.7 \\
\hline & Doctoral & 6 & 10.0 \\
\hline \multirow{3}{*}{ Age } & \multirow{3}{*}{$\begin{array}{l}20-30 \text { years old } \\
>30-40 \text { years old } \\
>40 \text { years old }\end{array}$} & 19 & 31.7 \\
\hline & & 32 & 53.3 \\
\hline & & 8 & 13.3 \\
\hline
\end{tabular}

\section{Randomization Testing}

Statistical checking is the first step in all experimental researches to ensure the effectiveness of randomization. Randomization can be declared as effective if there is no influence of demographic characteristics on subject's decision making. In this study, randomization testing was carried out using One Way ANOVA test and its results can be seen in Table 3.

Based on the results of the randomization effectiveness testing in table 3 , there is no influence on the demographic characteristics of gender, tenure, number of audit training, position in public accounting firm, recent education and age on the evaluation of fraud risk assessment. This is indicated by the level of significance of all demographic characteristic variables which are above 0.05 . So, it can be concluded that the results of inter-cell research in this study will actually be due to the manipulation given to each cell, not because of the influence of the demographic characteristics of the research subjects.

\section{Hypothesis Testing}

Hypothesis testing was done using between-subject test by comparing fraud risk assessment in group 1 and group 2 of subjects groups who received Diamond Fraud model treatment with high and low risk preferences. Hypothesis testing was also carried out to compare fraud risk assessment in group 3 and group 4 of subjects groups who received Pentagon Fraud model treatment with high and low risk preferences. The between-subject test results can be seen in Table 4. 


\begin{tabular}{|c|c|c|c|c|c|}
\hline & & Mean Square & Sig. & Information & \\
\hline \multirow[t]{2}{*}{ Gender } & Between Groups & 0,274 & & No Influence & \\
\hline & Within Groups & 0,234 & 0,331 & & \\
\hline \multirow{2}{*}{ Tenure } & Between Groups & 0,688 & & No Influence & \\
\hline & Within Groups & 0,925 & 0,744 & & \\
\hline \multirow[t]{2}{*}{$\begin{array}{l}\text { Number of } \\
\text { Audit } \\
\text { Training }\end{array}$} & Between Groups & 0,599 & & No Influence & \\
\hline & Within Groups & 0,414 & 0,159 & & \\
\hline \multirow[t]{2}{*}{$\begin{array}{l}\text { Position in } \\
\text { the public } \\
\text { accounting } \\
\text { firm }\end{array}$} & Between Groups & 0,663 & & No Influence & \\
\hline & Within Groups & 0,788 & 0,676 & & Table 3. \\
\hline \multirow{2}{*}{$\begin{array}{l}\text { Last } \\
\text { education }\end{array}$} & Between Groups & 0,501 & & No Influence & $\begin{array}{l}\text { Results of } \\
\text { Demographic }\end{array}$ \\
\hline & Within Groups & 0,392 & 0,254 & & Characteristics \\
\hline \multirow[t]{2}{*}{ Age } & Between Groups & 0,434 & & No Influence & Randomization \\
\hline & Within Groups & 0,565 & 0,769 & & \\
\hline
\end{tabular}

Dependent Variable: Fraud Risk Assessment

\begin{tabular}{|c|c|c|c|c|c|c|}
\hline Source & & $\begin{array}{l}\text { Type III } \\
\text { Sum of } \\
\text { Squares }\end{array}$ & Df & $\begin{array}{l}\text { Mean } \\
\text { Square }\end{array}$ & $\mathbf{F}$ & Sig. \\
\hline Corrected Model & & $4048.586^{a}$ & 3 & 1349.529 & 31.075 & .000 \\
\hline Intercept & & $\begin{array}{l}310140.65 \\
1\end{array}$ & 1 & $\begin{array}{l}310140.65 \\
1\end{array}$ & $\begin{array}{l}7141.5 \\
43\end{array}$ & .000 \\
\hline Fraud Model & & 2750.651 & 1 & 2750.651 & 63.339 & .000 \\
\hline Risk Preference & & 1111.551 & 1 & 1111.551 & 25.595 & .000 \\
\hline $\begin{array}{l}\text { Fraud Model } \\
\text { Risk Preference }\end{array}$ & $*$ & 186.384 & 1 & 186.384 & 4.292 & .043 \\
\hline Error & & 2431.950 & 56 & 43.428 & & \\
\hline Total & & $\begin{array}{l}316621.18 \\
8\end{array}$ & 60 & & & \\
\hline Corrected Total & & 6480.536 & 59 & & & \\
\hline
\end{tabular}

Table 4. BetweenSubject Test Results

a. $\mathrm{R}$ Squared $=.625$ (Adjusted R Squared $=.605$ )

\section{Hypothesis Test 1}

\section{Relationship between Alternative Fraud Model and Fraud Risk Assessment}

Hypothesis 1 of this study states that an auditor who uses Pentagon Fraud model will tend to carry out a more conservative fraud risk assessment than an auditor who uses Diamond Fraud model. Table 4 shows that, on average, fraud model as a consideration for performing fraud risk assessment is 2750.6. The statistical test results explain that the value

10.1 of Sig in the Test of Between-Subject Effect is 0,000 which is smaller than alpha (0.05) and thus it can be concluded that it is significant at the $5 \%$ probability level. The test results also explain that fraud model has a significant effect on fraud risk assessment. More 
precisely, Pentagon Fraud model will tend to create a more comprehensive fraud risk assessment compared to Diamond Fraud model.

A conservative attitude arises because an auditor is faced with the uncertainty of various threats of greater fraud. Thus, when the auditor uses Pentagon Fraud as his basis for fraud risk assessment, the model will produce more detailed information. Simon et al., (2018), stated that fraud models have benefits for conducting a fraud risk assessment. Hammersley (2011), stated that fraud models can show various signs of fraud threat. A high degree of arrogance influenced by high position and high ability will affect one's intention to commit a fraud (Vousinas, 2019). Individuals who have a tendency to face risk will use all necessary means to realize his desire. Boyle et al., (2015), argued that the use of Pentagon Fraud model will result a more comprehensive evaluation of fraud than the use of Diamond Fraud model.

\section{Hypothesis Test 2}

\section{Relationship between Auditor Risk Preference and Fraud Risk Assessment}

Hypothesis 2 in this study states that an auditor who has a low risk preference tend to be conservative compared to an auditor who has a high risk preference. Testing of hypothesis 2 was done using between-subject test method to compare high and low risk preferences on fraud risk assessment. Table 4 shows that the average risk preferences for consideration in performing fraud risk assessment is 1111.5. Statistical test results show that the value of Sig in between-subject test is 0,000 which is smaller than alpha (0.05) and thus it can be concluded that it is significant at the $5 \%$ probability level. The test results show that performing of fraud risk assessment is influenced by an auditor's risk preferences. Especially, an auditor who has a low risk preference is more conservative than an auditor who has a high risk preference.

Risk preferences tend to focus on behaviors that involve higher variation regardless of whether they are beneficial or detrimental (Rigoli et al., 2018). In facing of risk, all individuals have three tendencies, namely, avoiding risk, being neutral about risk and facing risk. Pressure, opportunity, and rationalization are elements of fraud risk that are often studied with a large number of literatures show the relationships between triangular elements of fraud and fraudulent financial reporting (Ruankaew, 2016). This study also connects auditors with risk assessment fraud (Johnson \& Silverman, 2010). Hammersley (2011), stated that the auditor's fraud-related tasks using assessment models shows concerns about unethical leadership that can affect the auditor's mental representation and generation of fraud hypotheses as an anticipation for fraud risk assessment.

An auditor with low risk preference tends to be careful when he makes decisions. Meanwhile, an auditor with high risk preference tends to take risks when he makes decisions. The level of auditor's risk preference will influence his fraud risk assessment. When an auditor has courage to take risks, the resulting fraud risk assessment is low. Risk preferences tend to focus on behaviors involving higher variance in audits, regardless whether they are beneficial or detrimental (Rigoli et al., 2018). An auditor with high risk preference will have a high level of confidence and will be bolder in taking high risks. When an auditor dares to take high risk, the resulting fraud risk assessment is low.

\section{Hypothesis Test 3}

Interaction of Fraud Model and Risk Preference with Fraud Risk Assessment 
The results of Hypothesis 1 and Hypothesis 2 show that the two independent variables i.e. fraud model and risk preference show significant results that underlie the determination of fraud risk assessment. Hypothesis 3 conjectures that there is an interaction between two independent variables on the determination of fraud risk assessment. Testing of hypothesis 3 using Two Way Anova can compare the mean difference between groups with independent variables. Based on the test results as shown in Table 4, it shows that all independent variables significantly influence dependent variables. The model is declared as valid. Intercept model shows Sig 0,000 which is smaller than alpha (0.5) indicating that without the influence of independent variables, the value of dependent variables can change.

Dependent Variable: Fraud Risk Assessment

$\begin{array}{lllll}\text { Fraud Model } & \text { Risk Preference } & \text { Mean } & \begin{array}{l}\text { Std. } \\ \text { Deviation }\end{array} & \mathrm{N} \\ \text { Diamond } & \text { High } & 67.6667 & 5.46635 & 15 \\ & \text { Low } & 62.5833 & 7.40214 & 15\end{array}$

\begin{tabular}{|c|c|c|c|c|c|}
\hline Pentagon & High & 84.7333 & 4.75795 & 15 & $\begin{array}{l}\text { Table } 5 . \\
\text { Descriptive } \\
\text { Statistics }\end{array}$ \\
\hline & Low & 72.6000 & 8.14862 & 15 & \\
\hline
\end{tabular}

Fraud model variables and risk preferences show a significant influence on performing of fraud risk assessment. The fraud model shows a significance of 0,000 and a risk preference variable also indicates a significance of 0,000 . Significance value of 0,000 which is below alpha 0.05 has proven that there is an influence of the dependent variable on the performing of fraud risk assessment. Thus, the first and second hypotheses are accepted. Interaction of fraud model and risk preference shows a value of 0.043 which is smaller than alpha (0.5) and so it can be concluded that the interaction between fraud model and risk preference significantly influences the performing of fraud risk assessment. Scores between groups can be seen in Table 6 .

Table 6 shows the score results from the testing of fraud model and risk preferences. Group 1 that received Diamond Fraud model treatment with high risk preference has a score of 67.66. Group 2 that received Diamond Fraud model treatment with low risk preference has a score of 62.58. Group 3 that received Pentagon Fraud model treatment with high risk preference has a score of 84.7. Group 4 that received Pentagon Fraud model treatment with low risk preference has a score of 72.60. Group 3 obtains the highest score which explains that when an auditor wants to determine the fraud risk assessment, he relies more on Pentagon Fraud model with high risk preference. Thus, the resulting fraud risk assessment is more comprehensive when an auditor uses Pentagon fraud model for performing fraud risk assessment. Group 2 obtains the lowest score which explains that when an auditor uses Diamond Fraud model to determine fraud risk assessment with low risk preference, the resulting fraud risk assessment is not conservative. The interaction of fraud models and risk preferences is illustrated in Figure 1.

JRAK Figure 1 shows that the first group that received Diamond Fraud model treatment with a high risk preference was at the point of estimated marginal means of 67.00. The second 10.1 group that received Diamond Fraud model treatment with low risk preference was at the point of estimated marginal means of 62.00. The third group that received Pentagon Fraud model treatment with a high risk preference was at the point of estimated marginal means 
of 85.00 and had the highest position compared to the other three conditions. The fourth group that received Pentagon Fraud model treatment with a low risk preference was at the estimated marginal means of 74.00 .

Figure 1.

Model Fraud

and Risk

Preference of

FRA

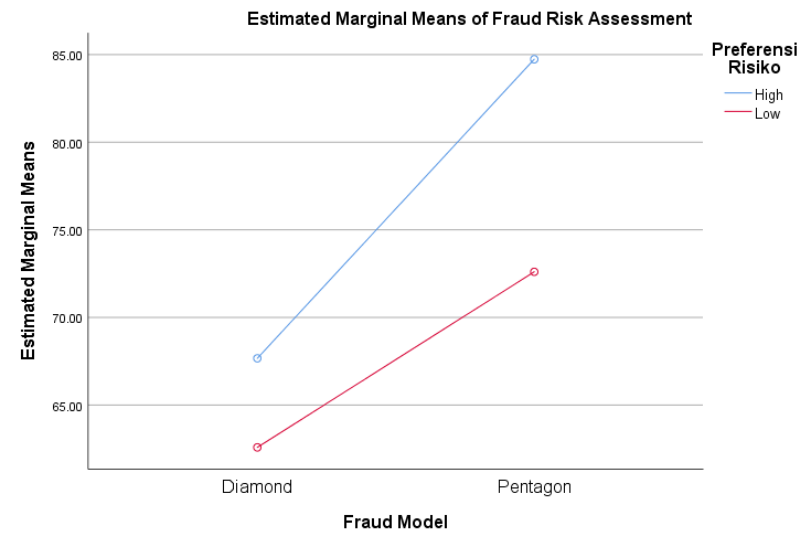

There is an interaction between the fraud model and risk preference, because auditor in performing an accurate fraud risk assessment requires a lot of consideration of factors causing fraud. Auditor needs a fraud model in conducting fraud risk assessment. Individuals who have a tendency to face risk will use all necessary means to realize their desire. Boyle et al., (2015), argued that the use of a fraud model based on Pentagon Fraud will result in a more conservative evaluation of fraud than the use of Triangle Fraud and Diamond Fraud. An auditor who chooses a high risk preference tends to be brave in taking high risk. When an auditor chooses a high risk preference, his fraud risk assessment will be conservative. The existence of fraud models and risk preferences can help auditors make a more accurate fraud risk assessment.

\section{CONCLUSION}

Fraud model is one of the factors in performing fraud risk assessment. Recently, the existing fraud models have been evolved and auditors use different fraud models in making fraud risk assessment. The development of fraud models certainly affects the auditor's judgment in making of fraud risk assessment. Risk preferences also become a factor when an auditor wants to make fraud risk assessment. Fraud risk assessment is an important part of the audit process and one of the toughest challenges faced by auditors. Fraud risk assessment that is made through various frameworks can make audit activities more effective. The more developed fraud model, the more detailed it is in revealing the triggering factor of fraud. This study compares Diamond Fraud model with Pentagon Fraud model related to risk preferences to determine fraud risk assessment. The testing in this study shows that fraud models have a significant effect on fraud risk assessment. The use of Pentagon Fraud model results a more conservative evaluation of fraud than the use of Diamond Fraud.

Second, this study finds that auditors who have low risk preferences tend to be conservative compared to auditors who have high risk preferences. Auditors with high risk preferences have a high level of confidence and are bolder in taking high risk. When auditors dare to take high risk, the resulting fraud risk assessment is low. Third, fraud models and risk preferences variables show a significant influence on the determination of fraud risk assessment. There is an interaction between fraud models and risk preferences because in order to determine an accurate fraud risk assessment auditors require a lot of consideration of the factors causing fraud. Auditors need fraud models in conducting fraud risk assessment. Individuals who have a tendency to face risk will use all necessary means 
to make their desires come true. Auditors with high risk preferences tend to be brave in taking high risk. When an auditor has a high risk preference, he will be conservative in conducting his fraud risk assessment. The existence of fraud models and risk preferences can help auditors make a more accurate fraud risk assessment.

The limitation in this study is that in conducting experiments there were some participants who made mistakes in filling out modules. Factors that influenced participants in making these mistakes include losing of concentration; not listening to the instructions; filling out modules in a hurry and approaching the lunch time; which these conditions result modules not passing the test. In addition, experimental participants in this study were very busy auditors, so that their focus on the experiment was potentially influenced by their seriousness.

The limitations of this study are expected to be a reference for other researchers to perfect and develop future research. Further researchers are expected to conduct more experiments on auditors' works and make better negotiation with auditors. Future studies are also expected not to use same variables and add new variables or modify previous variables with new variables. Pentagon Fraud model is suggested for public accounting firms as a basis for FRA decision making because it is more detailed and comprehensive.

\section{REFERENCES}

Abayomi, Sorunke, O. 2016. Personal ethics and fraudster motivation: the missing link in fraud triangle and fraud diamond theories. International Journal of Academic Research in Business and Social Sciences, 6(2), 159-165.

Abdullahi, R., \& Mansor, N. 2015. Fraud triangle theory and fraud diamond theory . understanding the convergent and divergent for future research. International Journal of Academic Research in Accounting, Finance and Management Sciences, 5(4), 38-45.

ACFE. 2016a. Fraud risk assessment.

ACFE. 2018. 2018 Global fraud study: report to the nation on occupational fraud and abuse asia-pacific edition, 1-28.

ACFE, I. C. 2016b. Survai fraud Indonesia 2016. ACFE Association of Certified Frand Examiners, 111(Chapter), 1-62.

Akbar, T. 2017. The determination of fraudulent financial reporting causes by using pentagon theory on manufacturing companies in indonesia. International Journal of Business, Economics and Law, 14(December), 106-113.

Anisykurlillah, I. 2016. The detection of fraudulent financial statement with fraud diamond analysis. Accounting Analysis Journal, 5(3), 173-181.

Annisya, M., Lindrianasari, \& Asmaranti, Y. 2016. Pendeteksian kecurangan laporan keuangan menggunakan fraud diamond. Jurnal Bisnis Dan Ekonomi, 23(1), 72-89.

Apriliana, S., \& Agustina, L. 2017. The analysis of fraudulent financial reporting determinant through fraud pentagon approach. Jurnal Dinamika Akuntansi, 9(2), 154 165.

JRAK Artani, K. T. B., \& Wetra, I. W. 2017. Pengaruh academic self efficacy dan fraud diamond terhadap perilaku kecurangan akademik mahasiswa akuntansi di bali. Jurnal Riset Akuntansi, 7(2), 123-132.

Bakhteev, A. 2015. model of integrated estimation of audit risk. Mediterranean Journal of Social 
Sciences, 6(3), 241-246.

Bawakes, H. F., Simanjuntak, A. M. ., \& Daat, S. C. 2018. Pengujian teori fraud pentagon terhadap fraudulent financial reporting. Jurnal Akuntansi dan Keuangan Daerah, 13(1), $114-134$.

Boyle, D. M., Dezoort, F. T., \& Hermanson, D. R. 2015. The effect of alternative fraud model use on auditors' fraud risk judgments. Journal of Accounting and Public Policy, 34(6), 578-596.

Chen, Y., Shapeero, M., \& Kong, C. 2016. Risk preference, decision mood and ceo financial statement fraud. 2016 International Conference Proceedings.

CNN. 2018. Kronologi kisruh laporan keuangan garuda indonesia. Retrieved from https://www.cnnindonesia.com/ekonomi/20190430174733-92-390927/kronologikisruh-laporan-keuangan-garuda-indonesia

Cohen, J. 2011. Corporate fraud and managers' behavior : evidence from the press. Journal of Business Ethics, 95(2010), 271-315.

Cotter, J., \& Hanly, J. 2010. Time-varying risk aversion: an application to energy hedging. Energy Economics, 32(2), 432-441.

Devi, K. L. S., Wahyuni, M. A., \& Sulindawati, N. L. G. E. 2017. Pengaruh frequent number of ceo's picture, pergantian direksi perusahaan dan external pressure dalam mendeteksi fraudulent financial reporting (studi empiris pada perusahaan farmasi yang listing di bei periode 2012-2016 ). E-Journal S1 Ak Universitas Pendidikan Ganesha, 8(2), $1-12$.

Eulerich, M., Georgi, C., \& Schmidt, A. 2019. Continuous auditing and risk-Based audit planning. SSRN Electronic Journal.

Free, C. 2015. Looking through the fraud triangle: a review and call for new directions. Australian School of Business, University of New South Wales, Kensington, Australia, Vol. 23 No(2049-372X.htm), 175-196.

Hammersley, J. S. 2011. A review and model of auditor judgments in fraud-related planning tasks. American Accounting Association, 30(4), 101-128.

Hoffmann, J. P. 2019. Risk preference theory and gender differences in religiousness: a replication and extension. Journal for the Scientific Study of Religion, 58(1), 210-230.

Johnson, R. E., \& Silverman, S. B. 2010. but actually inferior?: correlates and consequences of workplace arogance, 403-427.

Niemi, L., Knechel, W. R., Ojala, H., \& Collis, J. 2018. Responsiveness of auditors to the audit risk standards: unique evidence from big 4 audit firms. Accounting in Europe, 15(1), 33-54.

Nugraheni, N. K., \& Triatmoko, H. 2016. Analisis faktor-faktor yang mempengaruhi terjadinya financial statement fraud : perspektif diamond fraud theory. Jurnal Akuntansi Dan Auditing, 14(2), 118-143.

Payne, E. A., \& Ramsay, R. J. 2005. Fraud risk assessments and auditors' professional skepticism. Managerial Auditing Journal, 20(3), 321-330.

Rengganis, R. M. Y. D., Sari, M. M. R., Budiasih, I. G. A. ., Wirajaya, I. G. A., \& Suprasto, H. B. 2019. The fraud diamond: element in detecting financial statement of fraud. International Research Journal of Management, IT and Social Sciences, 6(3), 1-10.

JRAK 10.1 
Rigoli, F., Preller, K. H., \& Dolan, R. J. 2018. Risk preference and choice stochasticity during decisions for other people.

Ruankaew, T. 2016. Beyond the fraud diamond. International Journal of Business Management and Economic Research, 7(1), 474-476.

Sadikin, H., \& Adisasmito, W. 2016. Analisis pengaruh dimensi fraud triangle dalam kebijakan pencegahan fraud terhadap program jaminan kesehatan nasional di RSUP nasional cipto mangunkusumo. Jurnal Ekonomi Kesehatan Indonesia, 1(2), 28-34.

Septriani, Y., \& Handayani, D. 2018. Mendeteksi mecurangan laporan keuangan dengan analisis fraud pentagon. Jurnal Akuntansi, Keuangan Dan Bisnis, 11(1), 11-23.

Simon, C. A., Smith, J. L., \& Zimbelman, M. F. 2018. The influence of judgment decomposition on auditors' fraud risk assessments: some trade-offs, 93(5), 273-291.

Sonu, C. H., Ahn, H., \& Choi, A. 2017. Audit fee pressure and audit risk: evidence from the financial crisis of 2008*. Asia-Pacific Journal of Accounting and Economics, 24(1-2), 127-144.

Steinberg, L. 2013. The influence of neuroscience on, 14(July), 513-518.

Trompeter, G. M., Carpenter, T. D., Desai, N., Jones, K. L., \& Riley, R. A. 2013. A synthesis of fraud-related research. Auditing, 32(SUPPL.1), 287-321.

Utami, I., Kusuma, I. W., Gudono, \& Supriyadi. 2014. Halo effect in analytical procedure: the impact of client profile and information scope. Global Journal of Business Research, 8(1), 9-26.

Utami, I., \& Nahartyo, E. 2013. Riset eksperimental pengauditan: evolusi dan topik kontemporer. Jurnal Akuntansi Dan Keuangan Indonesia, 10(1), 60-79.

Utami, I., Noviyanti, S., Wijono, S., \& Mohamed, N. 2019. Fraud diamond, machiavellianism and fraud intention. International Journal of Ethics and Systems, 7(25149369), 1-14.

Vivianita, A., \& Indudewi, D. 2018. Financial statement fraud pada perusahaan pertambangan yang dipengaruhi oleh fraud pentagon theory ( studi kasus di perusahaan tambang yang terdaftar di bei tahun 2014-2016). Dinamika Sosial Budaya, 20(1), 1-15.

Vousinas, G. L. 2019. Advacing theory of fraud: the s.c.o.r.e model. Journal of Financial Crime, 26(1), 372-381.

Wen, F., He, Z., \& Chen, X. 2014. Investors risk preference characteristics and conditional skewness. Discrete Dynamics in Nature and Society, 2014, 1-9.

\section{JRAK}

\section{1}

